\title{
Soybean Futures Arbitrage: A Literature Review
}

\section{Yong Wang}

School of finance, Zhejiang University of Finance \& Economics, Hangzhou 310018, China

upcnku@163.com

\section{Keywords: Soybean futures; Arbitrage method; Arbitrage strategy}

\begin{abstract}
Soybean futures has been listed earlier in mainland China, while the cumulative volume of soybean futures is larger than other futures. This paper studies domestic and foreign achievements of soybean futures arbitrage from aspects of arbitrage methods and arbitrage strategies, and classifies these literatures. We should consider the price volatility of soybean futures and the long-term equilibrium relationship between soybean futures and other relative futures.
\end{abstract}

\section{Introduction}

In 2013, China's soybean imports were 6338 million tons. In 2014, China's total soybean imports reached 71.4 million tons, the first of which exceeded 70 million tons, up 12.7 percent from the same period last year. Imports of soybeans account for 85.61 percent of the domestic soybean market, compared with 12 million tons in China. According to the regulations, all imported soybeans must be used for crushing. The Chicago board of trade (CBOT) is the global soybean pricing center, and domestic soybean import enterprises mainly import trade based on CBOT pricing. Therefore, the domestic soybean crushing market is very dependent on international soybean price, which greatly restricts the development of domestic soybean crushing enterprises.

Soybean futures have been listed earlier in our commodity futures varieties, and transaction volume has increased year by year. Listed in Dalian commodity exchange since 1993, by the end of 2008, soybean futures contracts the cumulative volume and turnover reached 990 million, 990 million yuan, accounting for $45.72 \%$ of the Dalian commodity exchange cumulative volume, turnover and $45.97 \%$. According to the FIA world agricultural futures and options trading volume ranking, Dalian soybean futures listed on the ranks second in the world's top 20 agricultural products, Dalian commodity exchange as the world's second largest soybean futures market. Due to the lack of suitable strategies for soybean arbitrage, the frequent fluctuations of international soybean have brought great losses to the domestic soybean market. Therefore, this article through the analysis of the system of the literature of soybean futures arbitrage and comb, a comprehensive understanding of the soybean futures arbitrage, according to the problems existing in the domestic soybean crushing market put forward the corresponding solutions.

At present, the research on soybean futures arbitrage can be divided into two categories: the method of arbitrage of soybean futures, the research of cross-stage arbitrage, cross-market arbitrage and cross-commodity arbitrage. Another kind is from soybean futures arbitrage strategy, respectively from the process of soybean futures volatility and the Angle with the long-term equilibrium relationship between futures soybean futures arbitrage strategy. Of course, these two kinds of studies are not necessarily distinct, and many scholars are bound to study arbitrage strategies more or less in the research of arbitrage.

\section{Soybean Futures Arbitrage Methods}

Yanwei Tang (2006) [1] points out that futures arbitrage is a trading activity that takes advantage of the spread between the market or between contracts to hedge trades in related markets or related contracts. According to the existing arbitrage method, soybean futures arbitrage can be divided into three categories: cross-stage arbitrage, cross-market arbitrage and cross-commodity arbitrage.

Cross-term arbitrage refers to the trading activity which gains in the trading market by buying and selling futures contracts of different months of delivery of the same commodity. Domestic scholars 
such as Guijun Chen (2015) [2] choose Dalian Commodity Exchange of agricultural products futures soybean 1 main contract price data as the research object, to our country agricultural products futures arbitrage efficiency study, found that soybean between one part of the contract can be inter-temporal arbitrage.

Across the market arbitrage refers to in a market to buy (or sell) a particular delivery month of a commodity contract, at the same time in another market to sell (or buy) same goods of the same delivery month contracts and the trading behavior of profit. Foreign scholars such as Han, Liang and Tang (2013) [3] with vector error correction model (ECM) and structural vector autoregression model of CBOT and DCE soybean futures arbitrage across the market research, found the DCE soybean commodities futures prices can affect the CBOT soybean futures prices, then there is arbitrage space. Domestic scholars such as Hongfei Xie and Xiangyong Yuan (2006) [4] choose Dalian futures exchange may soybean futures contracts with the Chicago futures exchange may beans, arbitrage across the market analysis, found that both higher arbitrage between yield and relatively stable relations.

Across commodity arbitrage refers to the transactions in the market to buy a particular delivery month a commodity futures contracts, and sell the other same delivery month, interrelated commodity futures contracts and the trading behavior of profit. Foreign scholars such as Kenyon and Shapiro (1976) [5], Frank et al. (1989) [6] proved oil squeezed the price on the high side through the purchase of soybean futures at the same time when selling soybean meal, soybean oil futures to lock the high press spreads to increase revenue and reduce risk. Mitchell (2010) [7] think soybean, soybean meal and soybean oil squeezing spread between short-term deviate from the long-term equilibrium after will not necessarily mean reversion, on the basis of volatile conditions by adjusting the storehouse to increase price earnings ratio, so as to realize the cross between and among commodity arbitrage. Domestic scholars such as Feixue Huang and Zhihua Wang (2010) [8] select August 15, 2006 to December 18, 2009 in Dalian Commodity Exchange closing data of soybean and soybean meal using cointegration method to study before the financial crisis and financial crisis after the soybean and soybean meal price relationship between the influence each other. Yanwei Tang, Gang Chen and Yuhong Yang (2012) [9] choose Dalian Commodity Exchange of soybeans, soybean meal and soybean oil as the research object, as the research target, on soybean crushing profit is deduced based on squeezing profits of two kinds of soybean crushing arbitrage model of no-arbitrage condition.

\section{Soybean Futures Arbitrage Strategies}

Haigh and Holt (2002) [10] used GARCH model to study the short-term volatility of crushing, related futures hedge between arbitrage, found by using GARCH model to hedge arbitrage can improve the yield. Hornik et al. (1989) [11] used the neural network model to predict the short-term fluctuations of soybean crush spreads and had certain accuracy. Christian, Jason and Ben (2006) [12] by the model of MLP, RNN and HONN to analyze the short-term volatility of soybeans, soybean oil press, through the correlation filter for filtering, arbitrage efficiency improved significantly. Phoebe (2014) [13] used the RBF neural network, LM neural network and its squeezing the product of soybean meal, soybean oil price short-term volatility analysis predicts that found forward contracts affect the recent press spread profit, contract carry traders can according to this phenomenon.

Domestic scholars such as Tian Xia and Xiyu Cheng (2006) [14] used vector autoregressive (VAR) model, the error correction (VEC) model and variance decomposition technology for Dalian Commodity Exchange and the Chicago mercantile exchange, soybean futures prices and domestic soybean spot price relationship between the empirical research, found that there is a long-term equilibrium relationship between the three, the short-term price deviation can be corrected by its price restraint mechanism, there exist certain arbitrage opportunities. Sheng Yang et al. (2008) [15] used ADF unit root test method and association bean a reationship Dalian Commodity Exchange and soybean meal futures prices had carried on the empirical research and analysis, found between the two varieties of trading futures contract price long-term co-integration relationship, there is 
arbitrage space. Hao Yang and He Ma (2012) [16] selected soybean products, as a representative of the China's agricultural products by using cointegration test, error correction model, the empirical analysis methods, such as the Dalian Commodity Exchange (DCE) soybean with the Chicago mercantile exchange (CBOT), the relationship between the results found that DCE soybean futures prices and there is a long-term co-integration relationship CBOT soybean futures prices, including Chicago soybean futures market prices of soybean futures market plays a dominant role.

\section{Summary and Prospect}

Summary of Existing Soybean Futures Arbitrage. According to the existing domestic and international arbitrage research, the study of soybean futures arbitrage is largely focused on cross-commodity arbitrage in the arbitrage method. And soybean futures across commodity arbitrage strategy study are mostly based on time series method, mining arbitrage opportunities, through the establishment of futures price time series model, the fitting price fluctuation law, identifying the inner relationship of arbitrage portfolio, for two and two or more related futures arbitrage between relations, arbitrage strategy. Overall, the relevant results of existing soybean futures arbitrage mainly include the following characteristics:

In the research on soybean futures arbitrage way, mainly the arbitrage across goods, soybean futures studies and squeezing the soybean meal and soybean oil futures futures or arbitrage between the relationship among them. From the existing research results, overseas scholars mainly study the arbitrage relationship between soybean futures, soybean oil futures and soybean oil futures. Domestic scholars tend to study the arbitrage between soy and soybean meal, or soybean and soybean oil.

In the research of the soybean futures arbitrage strategy, the early research mainly applied the traditional equilibrium regression model method. This method mainly through econometric methods as cointegration and error correction model (ECM) regression model to analyze the long-term relationship between soybean and its related futures, so as to realize the arbitrage strategy. The application of this kind of method is very wide, and many scholars at home and abroad have used this method to carry out research work on the arbitrage strategy of soybean futures, and achieved a lot of results. Some scholars have also applied the GARCH model and so on, which has improved the yield of arbitrage to some extent.

More and more scholars are using the neural network model to study the strategy of soybean futures arbitrage. Foreign scholars have a lot of achievements in this research direction, and the neural network model is also quite diverse. But domestic scholars using neural network model to study the results of soybean futures arbitrage strategy is less, we are now one is mainly focus on the stock index futures and precious metals futures arbitrage strategy research. The second is the application of the neural network arbitrage model to compare single, mainly based on BP model, lack of contrast.

In addition, the sample data selected from relevant research results at home and abroad are mainly based on the closing price of trading day. This data selection method may lead to the failure to accurately reflect the price fluctuation of the day and the potential arbitrage opportunities. On the other hand, it could also lead to a more than one day of delay in the opening of the carry trade, resulting in a longer holding period and a loss of potential arbitrage opportunities.

Future Research and Prospect. Summarizing the research achievements of the predecessors, this paper argues that there is still room for further improvement in the research work of soybean futures arbitrage in some aspects. First of all, some research has focused on the long-term equilibrium relationship between study of commodity futures, and from there make effective arbitrage strategy of mutual relations, but ignore the one existing in the process of market volatility. Second, some research has focused on the use of different economic models to predict the trend of the futures price, according to the predicted price make effective arbitrage strategy, but ignored the goods in the process of a long-term equilibrium relationship between futures. Again, using the method of neural network model for domestic soybean futures arbitrage strategy research is still rare, domestic scholars is necessary to invest more in the research direction of resources, intensify 
research. Finally, in the sample data selection, the trading day's closing price is the main one. In view of this, it is necessary to make the arbitrage strategy of selecting sample data from the high frequency data of the trading day. This can both avoid long-term positions and improve returns.

\section{References}

[1] Y.W. Tang. Futures Spread Arbitrage, Beijing: economic science press, 2006.52-60.

[2] G.J. Chen. Empirical Research on the Arbitrage Efficiency of Agricultural Products in China. Price Theory and Practice, 2015, 02:91-93. (In Chinese)

[3]Han L.Y, Liang R and Tang K. Cross-market Soybean Futures Price Discovery: does the Dalian Commodity Exchange Affect the Chicago Board of Trade? Quantitative Finance, 2013, vol.13,No.4:613-626.

[4] H.F. Xie and X.Y. Yuan. The Arbitrage Analysis of Soybean Futures in China and the United States. Journal, 2006, 2007:146-148. (In Chinese)

[5] D.E. Kenyon and N.P. Shapiro. Profit Margin Hedging in the Broiler Industry, Futures Trading Seminar Proceedings. Board of Trade of the City of Chicago, 1976, vol.4,58-70.

[6] S.D. Frank, S.H. Irwin and G.H. Pfeiffer and C.E. Curtis. Further Evidence on Soybean Marketing Strategies: The Role of Options. North Central Journal of Agricultural Economics, 1989,vol.11,No.2:213-219.

[7] J.B. Mitchell. Soybean Futures Crush Spread Arbitrage: Trading Strategies and Market Efficiency. Journal of Risk \& Financial Management, 2010,vol.3,No.1:63-96.

[8] F.X. Huang and Z.H. Wang. Comparison of the Relationship between DCE Soybean and Soybean Meal Futures Before and After the Financial Crisis of Cointegration. Agricultural Technology Economy, 2010, 06:44-53. (In Chinese)

[9] Y.W. Tang, G. Chen and Y.H. Yang. No Arbitrage Conditions for the Arbitrage of Soybean Futures Cross Industrial Chain. Journal of Qingdao University (natural science edition), 2012, 03:84-87. (In Chinese)

[10] M.S. Haigh and M.T. Holt. Crack Spread Hedging: Accounting for Time-varing Spillovers in the Energy Futures Markets. Journal of Applied Economics, 2002,vol.17,No.3:269-280.

[11] K. Hornik, M. Stinchcombe and H. White. Multilayer Feed Forward Networks are Universal Approximators. Neural Neworks, 1989,vol.2,No.89:359-366.

[12] C.L. Dunis, J. Laws and B. Evans. Modelling and Trading the Soybean-oil Crush Spread with Recurrrent and Higher Order Networks: A Comparative Analysis. Neural Network World, 2006,vol.16,No.3:193-213.

[13] P.S. Wiles and D. Enke. Nonlinear Modeling using Neural Networks for Trading the Soybean Complex. Procedia Computer Science, 2014,vol.36,234-239.

[14] T. Xia and X.Y. Cheng. Research on the Dynamic Relationship Between Domestic and Foreign Futures Price and Domestic Spot Price: an Empirical Analysis Based on DCE and CBOT Soybean Futures Market and Domestic Soybean Market. Financial Research, 200602:110-117. (In Chinese)

[15] S. Yang, L.Y. He, S.D. Zhou and W.N. Zhang. Analysis of Co-integration of Soybean Meal and Soybean meal Futures Contract. China Management Science, 2008, S1:302-305. (In Chinese)

[16] H. Yang and H. Ma. Research on the Price Impact of China on International Commodity Agricultural Products - Empirical Analysis Based on Soybean Futures Market. China Management Science, 2012, S2:848-853. (In Chinese) 